\title{
OCCURRENCE AND CHARACTERIZATION OF ENTEROTOXIGENIC STAPHYLOCOCCI ISOLATED FROM SOFT CHEESES IN SERBIA
}

\author{
SAVIĆ RADOVANOVIĆ Radoslava ${ }^{1 *}$, ZDRAVKOVIĆ Nemanja ${ }^{2}$, \\ VELEBIT Branko ${ }^{3}$
}

${ }^{1}$ Department of Food Hygiene and Technology Faculty of Veterinary Medicine, University of Belgrade, Serbia; ${ }^{2}$ Scientific Institute of Veterinary Medicine of Serbia, Belgrade, Serbia; ${ }^{3}$ Institute of Meat Hygiene and Technology, Belgrade, Serbia

(Received 31 October 2019, Accepted 04 April 2020)

A total of 415 cheese samples produced with raw or cooked milk collected from local markets were analysed for the presence of coagulase-positive staphylococci. In 85 $(20.48 \%)$ samples the presence of coagulase positive staphylococci was detected. The ELFA technique VIDAS SET2 (BioMerieux, France) was used for testing coagulasepositive staphylococci strains to produce classical enterotoxins (SEA, SEB, SEC, SED, $\mathrm{SEE}$ ), and to determine the enterotoxins in cheese samples. The number of coagulasepositive staphylococci in cheese samples ranged from 1-5.79 $\log \mathrm{CFU} \mathrm{g}^{-1}$. Out of 85 coagulase-positive strains $26(30.59 \%)$ produced enterotoxins. The presence of genes for the synthesis of staphylococcal enterotoxins (SE) in the obtained extracts of DNA from 26 enterotoxigenic strains was detected by conventional multiplex PCR technique (for genes sea and seb) i.e. the Real-Time PCR technique for genes sec, sed and see. In all 26 strains of coagulase-positive staphylococci (originating from cheeses produced from raw or cooked milk, which were enterotoxin producers) sea was present, and in 24 strains in addition to sea gene, seb was detected. None of the isolates possessed genes for the synthesis of enterotoxin C (SEC), D (SED) and E (SEE). Out of 26 tested cheese samples positive for enterotoxigenic coagulase-positive staphylococci, enterotoxin was detected in $2(7.69 \%)$ samples of sweet-coagulating cheese, in which the number of enterotoxigenic coagulase-positive staphylococci exceeded $5 \log \mathrm{CFU} \mathrm{g}{ }^{-1}$. In sweetcoagulating cheeses in which the number of coagulase-positive staphylococci exceeds $5 \log \mathrm{CFU} \mathrm{g} \mathrm{g}^{-1}$ and the $\mathrm{pH}$ value was higher than 5.0, enterotoxins may be present in amounts sufficient to cause intoxication.

Key words: coagulase-positive staphylococci, enterotoxins, raw milk, cheeses

\section{INTRODUCTION}

Cheese as food takes a very important part in the human diet due to its high nutritional value. Cheeses have been traditionally produced in Serbia for centuries, representing

*Corresponding author: e-mail: mimica@vet.bg.ac.rs 
a cultural heritage and accumulated experimental knowledge, passed from generation to generation. Monasteries and feudal states were the main places where cheese production took place in the Middle Ages. The development of industrial production of cheese began in the early twentieth century, but still a significant portion of cheese, which can be found nowadays at greenmarkets in the Republic of Serbia, is produced in a traditional manner in small households. The individual producers use raw milk, cooked, or their mixture from the evening and/or morning milking. The coagulation process is carried out by addition of rennet, and no commercial starter cultures are used in the cheese production process. The native lactic acid bacteria are the main microbiota in the fermentation process and the ripening period usually lasts 7 to 10 days. Since a number of cheeses are produced from raw milk as part of the tradition, there is a possibility that pathogenic microorganisms, such as coagulase-positive staphylococci, pass from the milk to the cheese. Approximately $10 \%$ of cheese in Europe is made from raw milk [1] presenting a considerable potential risk to public health. Most cheeses at local markets in Serbia belong to the group of soft cheeses, which constitute, according to the Serbian legislation, the diversified cheese category which includes cheeses with $>67 \%$ water content in total solid matter without fat). The cheeses are divided in two groups: soft cheeses without ripening (aged to 7 days) and soft cheeses with ripening (longer than 7 days). Since the raw milk is used for production of soft cheeses present at the markets in Serbia, the data from the literature show that coagulase-positive staphylococci may be present in raw milk and there are no epidemiological reports that soft cheeses are reported as a cause of intoxication we undertook to examine the occurrence of enterotoxigenic coagulase-positive staphylococci in soft cheeses produced in small households in the Republic of Serbia.

Staphylococci are aerobic, facultative anaerobic bacteria, taxonomically belonging to the family Staphylococcaceae, genus Staphylococcus [2]. To date, more than 50 species and subspecies of staphylococci have been described. According to their potential to produce the enzyme coagulase they are divided into coagulase-positive (CPS) and coagulase-negative staphylococci (CNS). The main representative of the coagulasepositive staphylococciis Staphylococcus aureus subsp. aureus. As a ubiquitous microorganism Staphylococcus aureus (S. aureus) lives on the skin of humans and animals, and often colonizes the ductus papillaris of the mammary glands and may cause subclinical mastitis. In properly drawn milk, the typical counts of $S$. aureus are $100-200 \mathrm{CFU} / \mathrm{ml}$. In the case of subclinical mastitis, the counts may increase up to $10^{4} \mathrm{CFU} \mathrm{\textrm {ml } ^ { - 1 }}$. The natural ecological niches of $S$. aureus are the nasal cavity and skin of warm-blooded animals. The skin, mucosa membranes, teats and udders of dairy animals are the most important reservoir of this contaminant. It is responsible for approximately $30-40 \%$ of all mastitis cases in the world an important characteristic of the microorganism ability to produce extracellular enzymes and toxins, many of which are pathogenic for humans and animals. From the view point of milk hygiene, the ability of $S$. aureus to synthesize thermostable enterotoxins, that can cause food-borne poisoning of people, is important. Staphylococcal food poisoning (SFP) is one of the most common food- 
borne intoxication diseases, caused by enterotoxins produced mainly by Staphylococcus aureus ( $S$. aureus) strains. SFP is an intoxication resulting from the consumption of food containing sufficient amount $\left(1 \mu \mathrm{g} \mathrm{kg} \mathrm{kg}^{-1}\right.$ bodyweight consumer) of one or more enterotoxins.

To date, 23 staphylococcal enterotoxins (staphylococcal enterotoxins-SEs) and enterotoxin-like toxins (staphylococcal enterotoxin-like toxins-SEL) have been described [3-5]; enterotoxin A (SEA), B (SEB), C1 (SEC1), C2 (SEC2), C3 (SEC3), D (SED), E (SEE), G (SEG), H (SEH), I (SEI), J (SEJ) [6], K (SElK) [7], L (SEIL), M (SEIM), N (SEIN), O (SEIO) [8], P (SEIP) [9], Q (SElQ) [7], R (SEIR) [10], S (SEIS), T (SEIT) [5], U (SE/U) [11] and U2 and V, which are located on the cluster egc which encodes enterotoxin-like toxins synthesis [12]. Among the 23 SEs reported in literature only five SEA, SEB, SEC, SED, and SEE, different in antigenic reaction recognized as a classic enterotoxins can be identified with commercially available immunoassay kits. Staphylococcal enterotoxins have been the cause of $6.4 \%$ of food-borne outbreaks in the European Union (EU) in 2012, placing bacterial toxins as the third most common outbreak causative agent in the EU [1]. In the USA, S. aureus was ranked as one of the five most frequent causes of food-borne outbreaks with more than 240,000 illnesses annually. According to the EFSA record from 2014 year 777 outbreaks in 2012 were caused by the toxins of Bacillus spp., Clostridium spp. and coagulase-positive staphylococci. SFP takes the second place among food borne diseases. Out of the total number of recorded disorders 346 were caused by staphylococcal enterotoxin and cheese caused $20 \%$ of alimentary intoxications. The food, associated with staphylococcal enterotoxin poisoning is the one rich in proteins, which is produced in artisanal conditions and when the production process is followed by manual manipulation, often in combination with inadequate thermal processing and storage. Often many of these cases of poisoning remained undetected because the incubation period was short, small outbreaks are not reported, due to mistakes in the diagnosis, irregularities during sampling, i.e. errors in laboratory diagnostics. For the formation of a sufficient amount of enterotoxins able to cause intoxication must be more than $10^{5} \mathrm{CFU} S$. aureus $\mathrm{g}^{-1}$ of cheese $[13,14]$.

According to the official record of the Health Statistical Yearbook [15] during 2013, in Serbia, 749 cases of bacterial food intoxication were reported, the ethological agents not being specified. Since the data are insufficient in number of SFP and cheeses as food rarely reported as the cause of food poisoning even they are often purchased at markets and consumed fresh in accordance to consumers' habits, the aim of this study was to examine the occurrence of enterotoxigenic coagulase-positive staphylococci in soft cheeses.

The aim included: (1) to determine the number of coagulase-positive staphylococci in cheese samples traditionally produced in small households originating from different geographical localities in the Republic of Serbia collected at green markets in Belgrade, (2) to identify isolated strains of coagulase positive staphylococci and characterize them on the basis of their ability to produce staphylococcal enterotoxins (ses), (3) 
to determine the presence of genes for enterotoxin synthesis (4) to determine the presence of enterotoxins in the cheese matrix.

\section{MATERIAL AND METHODS}

\section{Sampling}

The total of 415 cheese samples produced with raw or cooked cows' milk was collected at 17 green markets in the city of Belgrade. The cheeses of different age, were traditionally produced in individual households without the addition of commercial starter cultures originating from different geographical localities (Figure 1). The samples were aseptically collected in sterile plastic bags according to ISO 707:2008 (IDF 50:2008) standard and transferred under refrigeration (at about $4^{\circ} \mathrm{C}$ ) to the laboratories where they were immediately analysed.

Coagulation in all cheese samples was due to the addition of rennet. The $\mathrm{pH}$ value of cheeses was the criteria for dividing cheese samples into 2 groups: acid-coagulating and sweet-coagulating cheeses. All cheeses in which the $\mathrm{pH}$ value measured was more than 4.6 were classified into the group of sweet-coagulating and $\mathrm{pH}$ less than 4.6 into the group of acid-coagulating cheeses [16]. Out of 415 cheese samples 126 were acid-coagulating and 289 sweet-coagulating cheeses. The age of cheese samples was determined on the basis of the results obtained from the given questionnaire to individual producers. Cheese samples aged under 7 days were classified into the group of cheeses without ripening and cheese samples aged longer than 7 days into group of cheeses with the ripening phase according to legislation [17].

\section{Isolation and enumeration of coagulase-positive staphylococci}

Cheese samples $(20 \mathrm{~g}$ ) were diluted in $180 \mathrm{~mL}$ of buffered peptone water (LAB,Bury, Lancashire, U.K.), homogenized in a BagMixer (Interscience). Sample homogenates were tenfold diluted in buffered peptone water and the dilutions then plated in duplicate on selective culture media. In order to isolate and enumerate coagulasepositive staphylococci, the standard ISO 6888 method with Baird Parker medium was used [18]. The limit of detection was $100 \mathrm{CFU} \mathrm{g}^{-1}$. The typical five colonies (circular, black, smooth, convex, with perfect edges, surrounded by an opaque zone and/or transparent halo) per sample were subjected to Gram staining, catalase test and coagulase test. Gram, catalase and coagulase positive strains were biochemically identified, using the ID 32 Staph-Biomerieux (BioMérieux, France) to the species level on the basis of their biochemical characteristics.

\section{Strains}

One strain of coagulase-positive staphylococci per positive cheese sample was examined to detect the ability to synthesize SEs, described as follows: 85 strains were tested for the staphylococcal enterotoxins and 26 strains enterotoxin producers were 


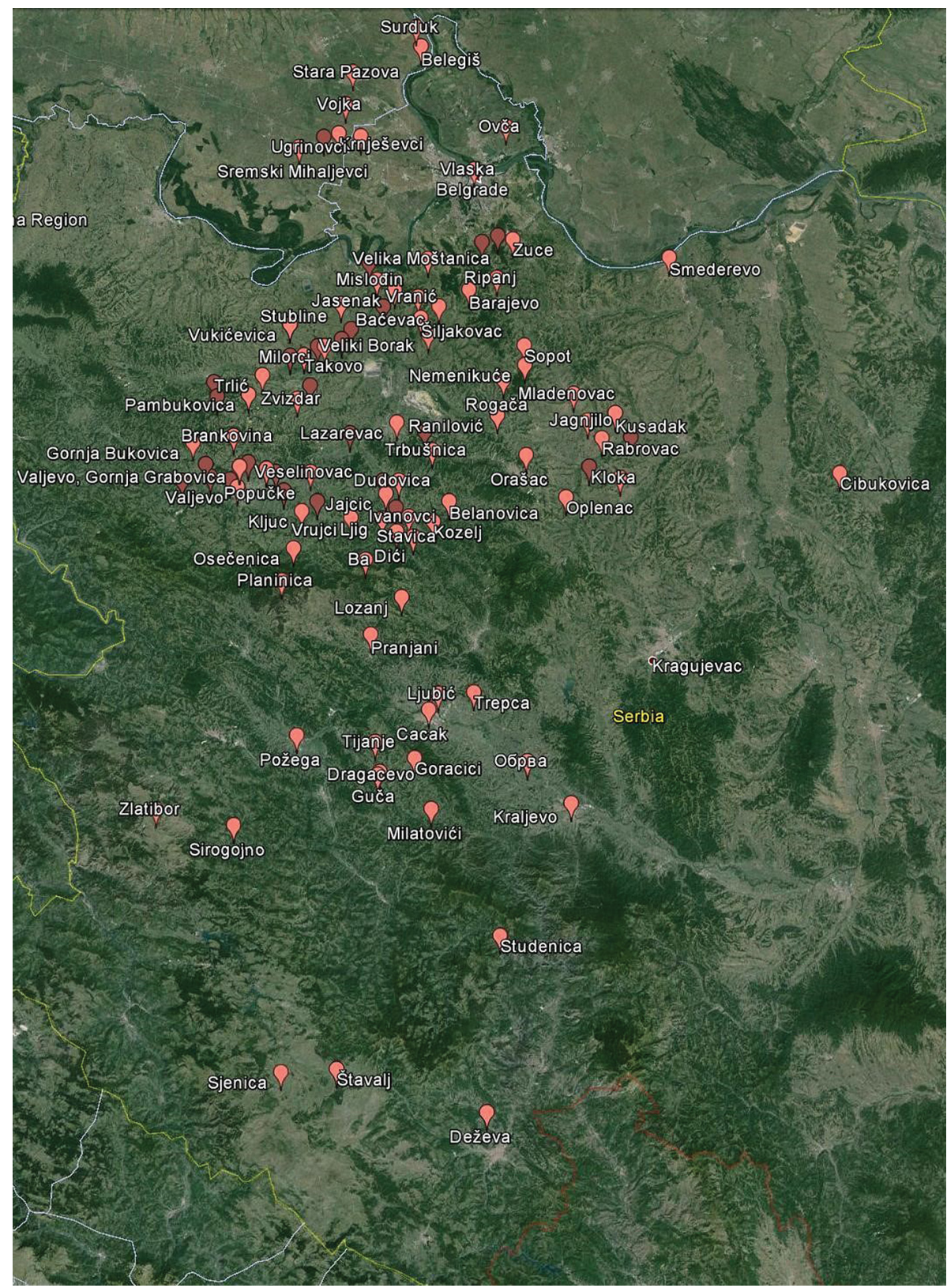

Figure 1. Geographycal origin of cheese samples collected at Belgrade markets

tested for presence of genes for enterotoxin synthesis. Each strain was stored in nutrient agar slant prior to the analysis. Type strain Staphylococcus aureus ATCC 25923, as well as strains Staphylococcus aureus aureus CIP 67.8, enterotoxin A i enterotoxin B producers were kindly provided by The Institute of Meat Hygiene and Technology, Belgrade and used as control. 


\section{Enumeration of lactic acid bacteria}

Determination the number of Lactococcus spp. and Lactobacillus spp. was performed by the standard ISO27205 (IDF 149:2010) method [19].

\section{Chemical analysis}

The $\mathrm{pH}$ value was measured with a $\mathrm{pH}-$ meter (pH-Vision 246071 Extech instruments), the water activity by $a_{w}$-meter (GBX Scientific Instruments, FA-st/1 tastatura: Model MX 3700/ML 4700). Sodium chloride $(\mathrm{NaCl})$ content in cheese samples was determined by the titrimetric method [20].

\section{Determination of staphylococcal enterotoxins}

The ELFA technique VIDAS® Staph enterotoxin II (SET2; bioMeriéux, REF 30 $705,2004)$ was used for the detection of classical enterotoxins SEA, SEB, SEC, SED and SEE, using the equipment Mini VIDAS (bioMérieux, France), with the detection limits of $0.5 \mathrm{ng} \mathrm{ml}^{-1}$ for SEA and SEB, and of $1.0 \mathrm{ng} \mathrm{ml}^{-1}$ for SEC-SEE. The isolates were cultured for $24 \mathrm{~h}$ aerobically in $10 \mathrm{~mL}$ BHI broth (Merck, Germany) at $37^{\circ} \mathrm{C}$. Bacterial culture supernatants were collected by centrifugation at $7000 \mathrm{~g}$ for $10 \mathrm{~min}$. and the $\mathrm{pH}$ value was adjusted to $7.5-8$. The aliquot $(500 \mu \mathrm{L})$ was transferred directly into the well of the VIDAS SET2 strip. As the ELFA technique does not allow the quantitative detection of SEs, the results are expressed as either positive or negative.

\section{PCR amplification}

The presence of se genes encoding the synthesis of staphylococcal enterotoxins (SE) in the obtained extracts of DNA from 26 enterotoxigenic coagulase-positive isolates was detected by the conventional multiplex PCR technique (for genes sea and seb) i.e. the Real-Time PCR technique (for genes sec, sed and see). The primers used in this work, their sequences, and size of fragments are summarised in Table 1.

Table 1. List of primers used for determination of genes for staphylococcal enterotoxins

\begin{tabular}{|c|c|c|c|}
\hline Primer & Target gen & $\begin{array}{c}\text { Length of } \\
\text { ampliphied } \\
\text { sequance (bp) }\end{array}$ & Sequence \\
\hline $\begin{array}{l}\text { sea-f } \\
\text { sea-r }\end{array}$ & sea & 93 & $\begin{array}{l}\text { 5'-TCAATTTATGGCTAGACGGTAAACAA-3' } \\
\text { 5'- GAAGATCCAACTCCTGAACAGTTACA -3' }\end{array}$ \\
\hline $\begin{array}{l}\text { seb-f } \\
\text { seb-r }\end{array}$ & seb & 85 & $\begin{array}{l}\text { 5'- AACAACTCGCCTTATGAAACGGGAT -3' } \\
\text { 5'- CTCCTGGTGCAGGCATCATGTCA -3' }\end{array}$ \\
\hline $\begin{array}{l}\text { sec-f } \\
\text { sec-r }\end{array}$ & $\mathrm{sec}$ & 284 & $\begin{array}{l}\text { 5'- CGTAT'TAGCAGAGAGCCAACCA - 3' } \\
\text { 5'- GTGAATT'TACTCGCT'T'TGTGCAA -3' }\end{array}$ \\
\hline $\begin{array}{l}\text { sed-f } \\
\text { sed-r }\end{array}$ & sed & 150 & $\begin{array}{l}\text { 5'- AAACGTTAAAGCCAATGAAAACA -3' } \\
\text { 5'- TGATCTCCTGTACT'T'TATT'T'TCTCCTA -3' }\end{array}$ \\
\hline $\begin{array}{l}\text { see-f } \\
\text { see-r }\end{array}$ & see & 171 & $\begin{array}{l}\text { 5'- TACCAATTAACTTGTGGATAGAC -3' } \\
\text { 5'- CTCTTTGCACCTTACCGC -3' }\end{array}$ \\
\hline
\end{tabular}




\section{RESULTS}

This study included cheese samples of different ages, produced in small households from different geographical localities in Serbia (Figure 1). Bacteriological findings of cheese samples with coagulase-positive staphylococci are presented in Table 2. Out of 415 cheese samples in $85(20.48 \%)$ cheese samples were detected coagulase-positive staphylococci. The number of coagulase-positive staphylococci in cheese samples ranged from 1-5.79 log CFU g-1 (Table 3).

Table 2. Occurence of coagulase-positive staphylococci in cheese samples

\begin{tabular}{lcccccccc}
\hline & & \multicolumn{4}{c}{ Positive for coagulase-positive staphylococci } \\
\cline { 3 - 9 } Type of cheese & $\begin{array}{c}\text { Number } \\
\text { of samples } \\
\text { (n) }\end{array}$ & $\begin{array}{c}\text { Cheeses produced } \\
\text { with cooked milk }\end{array}$ & $\begin{array}{c}\text { Cheeses produced } \\
\text { with raw milk }\end{array}$ & \multicolumn{2}{c}{ Total } \\
\cline { 3 - 9 } & & Number & \% & Number & $\%$ & Number & $\%$ \\
\hline Acid-coagulating & 126 & 1 & 0.79 & 18 & 14.29 & 19 & 15.08 \\
\hline Sweet-coagulating & 289 & 23 & 7.96 & 43 & 14.89 & 66 & 22.84 \\
\hline Total & 415 & 24 & 5.78 & 61 & 14.70 & 85 & 20.48 \\
\hline
\end{tabular}

Table 3. Contamination level of cheese samples with coagulase-positive staphylococci

\begin{tabular}{|c|c|c|c|c|c|c|c|c|c|c|}
\hline \multirow{3}{*}{$\begin{array}{c}\text { Level of } \\
\text { contamination }\end{array}$} & \multicolumn{5}{|c|}{ Sweet-coagulating cheeses } & \multicolumn{5}{|c|}{ Acid-coagulating cheeses } \\
\hline & \multirow{2}{*}{$\begin{array}{l}\text { Number of } \\
\text { samples } \\
\text { (n) }\end{array}$} & \multicolumn{2}{|c|}{$\begin{array}{c}\text { Cooked } \\
\text { milk }\end{array}$} & \multicolumn{2}{|c|}{$\begin{array}{l}\text { Raw } \\
\text { milk }\end{array}$} & \multirow{2}{*}{$\begin{array}{l}\text { Number of } \\
\text { samples } \\
\text { (n) }\end{array}$} & \multicolumn{2}{|c|}{$\begin{array}{l}\text { Cooked } \\
\text { milk }\end{array}$} & \multicolumn{2}{|c|}{$\begin{array}{l}\text { Raw } \\
\text { milk }\end{array}$} \\
\hline & & $\mathrm{n}$ & $\%$ & $\mathrm{n}$ & $\%$ & & $\mathbf{n}$ & $\%$ & $\mathrm{n}$ & $\%$ \\
\hline$\leq 2 \log \mathrm{cfu} / \mathrm{g}$ & 6 & 4 & 66.67 & 2 & 33.33 & 3 & 1 & 33.33 & 2 & 66.67 \\
\hline $2-5 \log \mathrm{cfu} / \mathrm{g}$ & 47 & 20 & 42.55 & 27 & 57.45 & 13 & 0 & 0.00 & 13 & 100 \\
\hline$>5 \log \mathrm{cfu} / \mathrm{g}$ & 13 & 3 & 23.08 & 10 & 76.92 & 3 & 0 & 0.00 & 3 & 100 \\
\hline Total & 66 & 27 & 40.91 & 39 & 59.09 & 19 & 1 & 5.26 & 18 & 94.74 \\
\hline
\end{tabular}

Out of 85 cheese samples positive for coagulase- positive staphylococci $26(30.59 \%)$ were positive for enetrotoxigenic staphylococci from which $20(23.53 \%)$ were produced of raw milk and $6(7.06 \%)$ of cooked milk (Table 4). All 26 isolates (one per positive sample) were identified by MPCR reaction as belonging to $S$. aureus. The ID 32 Staph-Biomerieux identification was in agreement with that the PCR reaction. Since the ELFA technique used in the experiment, detected the group of classical enterotoxins (SEA-SEE), it was decided to identify se genes encoding the synthesis of one or more toxins. All 26 isolates produced classical eneterotoxins (SEA-SEB). DNA extracted from those staphylococcal isolates was used for testing for enterotoxin genes using the conventional multiplex PCR for genes sea and seb (Figure 2), or the 
technique of Real-Time PCR for genessec, sed and see (Figure 3).Origin of isolates positive to enterotoxin genes revealed that more isolates came from sweet coagulating cheeses, than acid and more came from raw than cooked milk (Table 4). In all 26 isolates of coagulase-positive staphylococci originating from cheeses produced from raw/cooked milk (which were enterotoxin producers) the gene for enterotoxin A (sea) was detected, and in 24 isolates in addition to the sea gene, the gene for the synthesis of enterotoxin B (seb) was detected. None of the isolates possessed the genes for the synthesis of enterotoxin C (sec), D (sed) and E (see) (Table 6). Out of 26 tested cheese samples positive for enterotoxigenic coagulase-positive staphylococci, enterotoxin was detected in $2(7.69 \%)$ samples which were sweet-coagulating cheese, made from raw milk, and the number of coagulase-positive staphylococci exceeded $5 \log \mathrm{CFU} \mathrm{g}^{-1}$.

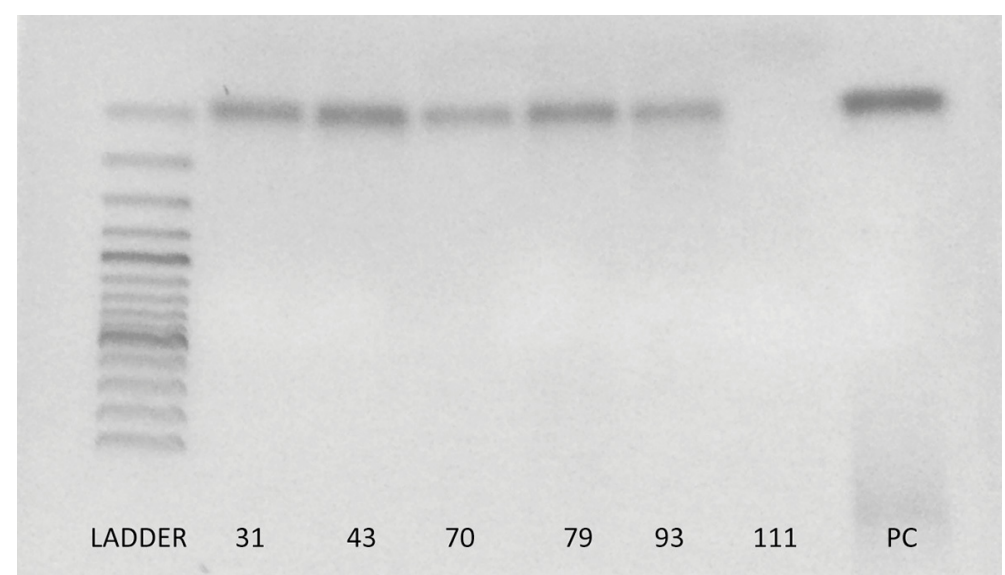

Figure 2. Results of PCR electrophoresiss for produts obtained by primers for seb gen. M marker (GeneRuler 100 bp Plus DNA Ladder). PC-positive control

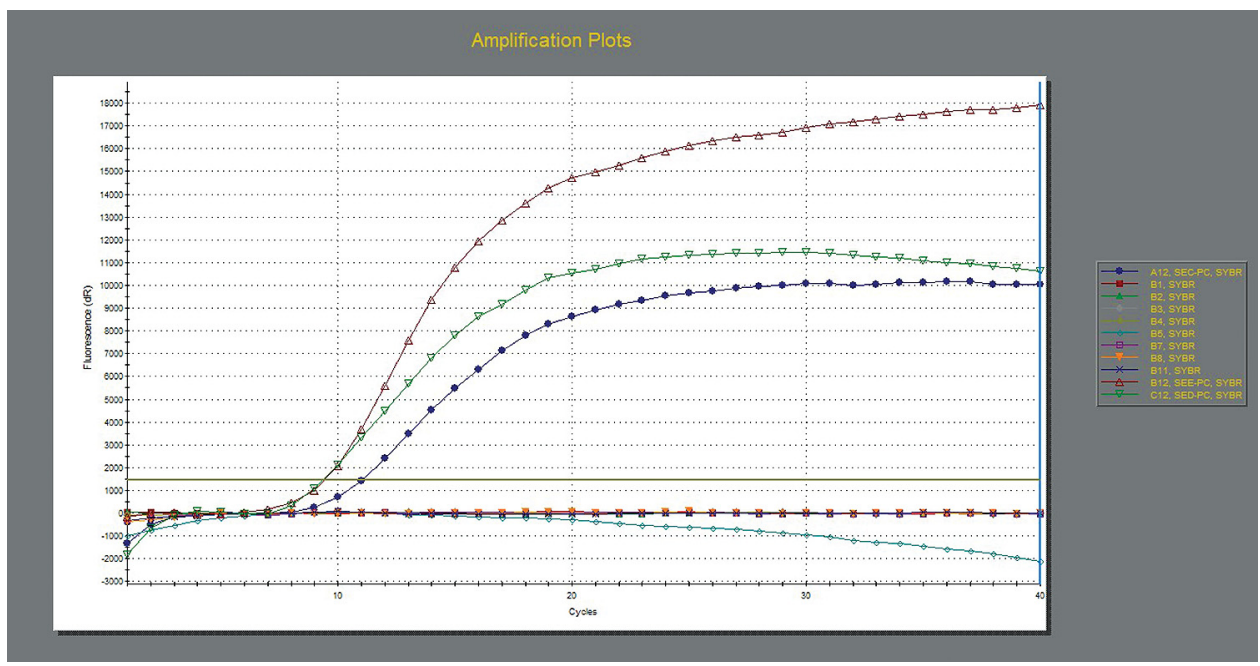

Figure 3. Amplification curve of genes sec, sed and see of samples and positive control 
Table 4. Origin of enterotoxigenic coagulase-positive staphylococci isolates in cheese samples

\begin{tabular}{|c|c|c|c|c|c|c|}
\hline \multirow{3}{*}{$\begin{array}{l}\text { Type of } \\
\text { cheese }\end{array}$} & \multirow{3}{*}{$\begin{array}{c}\text { Finding of } \\
\text { coagulase- } \\
\text { postive } \\
\text { Staphylococci }\end{array}$} & \multicolumn{5}{|c|}{$\begin{array}{l}\text { Origin of coagulase-postive staphylococci positive to } \\
\text { enterotoxine genes } \\
\text { (n) }\end{array}$} \\
\hline & & \multirow{2}{*}{ (n) } & \multicolumn{2}{|c|}{ Cooked milk } & \multicolumn{2}{|c|}{ Raw milk } \\
\hline & & & Number & $\%$ & Number & $\%$ \\
\hline $\begin{array}{c}\text { Acid- } \\
\text { coagulating }\end{array}$ & 19 & 6 & 1 & 3.85 & 5 & 19.23 \\
\hline $\begin{array}{c}\text { Sweet- } \\
\text { coagulating }\end{array}$ & 66 & 20 & 5 & 19.23 & 15 & 57.69 \\
\hline Total & 85 & 26 & 6 & 23.08 & 20 & 76.92 \\
\hline
\end{tabular}

Table 5. Number of coagulase-positive staphylococci, Lactococcus spp, Lactobacillus spp. and physico-chemichal parameters $\left(\mathrm{pH}, \mathrm{a}_{\mathrm{w}}\right.$ and $\mathrm{NaCl}$ content)

\begin{tabular}{cccccc}
\hline & $\mathbf{n}$ & $\begin{array}{c}\overline{\mathbf{x}} \pm \mathbf{S D} \\
(\mathbf{l o g} \mathbf{c f u} / \mathbf{g})\end{array}$ & $\mathbf{X m i n}$ & $\mathbf{X m a x}$ & $\mathbf{C v}(\%)$ \\
\hline $\begin{array}{c}\text { Cagulase-positive } \\
\text { staphylococci (log cfu/g) }\end{array}$ & 85 & $3,60 \pm 1,19$ & 1,00 & 5,79 & 33,27 \\
\hline $\begin{array}{c}\text { Lactococcus } \text { spp. } \\
\text { (log cfu/g) }\end{array}$ & 85 & $8,33 \pm 0.55$ & 7,02 & 9,80 & 6,58 \\
$\begin{array}{c}\text { Lactobacillus spp. } \\
(\log \mathrm{cfu} / \mathrm{g})\end{array}$ & 85 & $6,62 \pm 0,95$ & 4,00 & 9,19 & 14,43 \\
$\mathrm{pH}$ & 85 & $4,98 \pm 0,50$ & 4,30 & 6,25 & 10,16 \\
$\mathrm{a}_{\mathrm{w}}$ & 85 & $0,95 \pm 0,02$ & 0,82 & 0,977 & 2,42 \\
\hline $\mathrm{NaCl}(\%)$ & 85 & $1,10 \pm 0,71$ & $<0,01$ & 3,48 & 64,31 \\
\hline
\end{tabular}

Table 6. The presence of genes encoding the synthesis of enterotoxins in coagulase-positive staphilococci isolates from samples of soft cheeses

\begin{tabular}{cccccccccccc}
\hline \multirow{2}{*}{$\begin{array}{c}\text { Species of } \\
\text { staphylococci }\end{array}$} & $\begin{array}{c}\text { Number } \\
\text { of isolates }\end{array}$ & \multicolumn{2}{c}{ sea gen } & \multicolumn{2}{c}{ seb gen } & \multicolumn{2}{c}{ sec gen } & \multicolumn{2}{c}{ sed gen } & \multicolumn{2}{c}{ see gen } \\
\cline { 3 - 13 } & & Br. & $\%$ & Br. & $\%$ & Br. & $\%$ & Br. & $\%$ & Br. & $\%$ \\
\hline S. aureus & 26 & 26 & 100 & 24 & 92.31 & 0 & 0 & 0 & 0 & 0 & 0 \\
\hline
\end{tabular}

\section{DISCUSSION}

The bacteriological analysis of 415 soft cheese samples showed the presence of coagulase-positive staphylococci in $85(20.48 \%$ ) samples of soft cheeses (Table 2). Our results are in accordance with the results of Araújo et al. [21], who detected coagulase-positive staphylococci in $20 \%$ of soft cheese samples in Brazil. Similar results were obtained by De Luca et al. [22] while El-Sharoud and Spano [23] did not detect $S$. aureus in soft cheese samples from local markets in Egypt. On the other hand, 
in Rosengren et al. [24] survey, coagulase-positive staphylococci were detected in 69\% $(38 / 55)$ of the raw milk cheese samples whereas the occurrence in cheeses made from pasteurized milk was $6 \%$ (6/96). The number of S. aureus ranges from $100-200 \mathrm{cfu} / \mathrm{ml}$ in the milk obtained by proper milking, while this number increases up to $10^{4} \mathrm{CFU} \mathrm{ml}^{-1}$ in the case of latent infection in the mammary glands [25]. The number of coagulasepositive staphylococci greater than $10^{4} \mathrm{CFU} \mathrm{g}^{-1}$ cheese produced from raw milk was the result of primary contamination of milk due to latent infection or subclinical mastitis. The presence of coagulase-positive staphylococci in cheese made of raw milk points to subclinical mastitis or poor hygiene during the cheese making process. The control of $S$. aureus growth during the fermentation of raw milk cheese means prevention against staphylococcal enterotoxin production. In addition to the origin of coagulasepositive staphylococci are data from previous findings and the frequent occurrence of coagulase-positive staphylococci in milk [26-32]. The occurrence of coagulase-positive staphylococci in cheeses produced from cooked milk can be explained by the poor hygiene and subsequent contamination from the environment, from dirty hands of workers and equipment, whereas a high water activity (0.94 to 0.96) and high $\mathrm{pH}$ value (6.0- 6.2) in the cheese enable their growth. In addition to the contamination originating from humans are data of the frequency of enterotoxigenic staphylococci in food processing workers of 17\% [33]. The SEA toxin was found to be more prevalent in food processing human carriers than in food itself, but other forms of toxin are found to have opposing prevalence [34].

Cheese production process is a complex one. Behaviour of $S$. aureus in cheese depends on the production process and the capacity of the microorganism to survive stress in the cheese matrix [35]. In the Republic of Serbia soft cheeses are produced in a traditional manner in individual households from cooked or raw milk. The milk from the morning, evening, or mixture from both milkings is used. If the cheese is produced with the mixture from evening and morning milking, evening milk is kept in a cool state during the night, but small producers often keep the milk at room temperature which are conditions that are favourable for the growth of coagulasepositive staphylococci. Observing the soft cheese production process, conditions for $S$. aureus growth, especially in the early stages $(\mathrm{pH}$ value and temperature) are favourable. The growth of the microorganism is possible until the physico-chemical parameters ( $\mathrm{pH}$, water activity, $\mathrm{NaCl}$ content) and the presence of competitive microbiota begin to affect the growth of $S$. aureus. Environmental conditions in which cheeses are produced, especially during the warm months of the year (Spring and Summer) favour the growth of coagulase-positive staphylococci. Thus during the manufacture and storage of soft cheese coagulase-positive staphylococci can multiply and produce enterotoxins, especially in the case of cheese production without lactic acid fermentation, such as it is in sweet-coagulating cheeses. The conditions during the production of soft cheeses with fresh coagulation, when the $\mathrm{pH}$ of the cheese is over 4.6 favoured the growth and multiplication of coagulase-positive staphylococci. 
According to the literature [36], the growth of this microorganism is in a $\mathrm{pH}$ range from 4 to 10, and optimally at a $\mathrm{pH}$ of 6-7 which is weakly acidic.

Our results showed that out of 85 isolates of coagulase-positive staphylococci 26 $(30.59 \%)$ isolates produced enterotoxins (Table 4). Since we detected a group of classical enterotoxins (SEA-SEE) by application of screening method VIDAS SET 2 (BioMerieux, France), we were unable to determine which of five classical enterotoxins produce isolates of coagulase-positive staphylococci, so we decided to identify genes for the synthesis of enterotoxin. Out of 85 enterotoxigenic isolates in $26(30.59 \%)$ isolates were detected sea; while in 24 isolates, in addition to sea gene, seb was detected. In none of the isolates sec, sed and see were detected (Table 6). Our results are in accordance to the results of Medvedova et al. [37], who detected genes for the synthesis of enterotoxins (SEA-SEE) in 32\% S. aureus isolates originating from milk and other dairy products. Among se gens, sea was the predominant, but the authors did not detect seb gen in contrast to our results. Our results agree with literature data for the predominance of enterotoxin A (SEA) recorded in different countries of the world. In the UK, during an extensive monitoring of the epidemic in the period from 1969 to $1990,79 \%$ of the isolates of $S$. aureus were SEA producers [38]. In France the enterotoxin A (SEA) is cited as the most common cause of poisoning $(69.7 \%)$ in 31 outbreaks, reported in the period 1981-2002, and caused by different food, such as milk, milk products, meat and salads. The most common in the se outbreaks were sea, then sed, seg, sei and seh, rarely seb and sec; while the see gene was not detected [39], and our results agree with this findings of sea gene, but differ in terms of finding other genes because sec and sed genes were not detected.

Examining the presence of enterotoxins in 26 cheese samples positive for eneterotoxigenic staphylococci enterotoxins were detected in two cheese samples in which the number of coagulase-positive staphylococci exceeded $5 \log \mathrm{CFU} \mathrm{g}{ }^{-1}$. In coagulase-positive staphylococci isolates, originating from these two cheese samples sea and seb gens were detected. The isolates were identified as Staphylococcus aureus based on biochemical characteristics. The $\mathrm{pH}$ value in cheese samples was 5.08 and 5.35 , and water activity was 0.960 and 0.962 , respectively, which are also growth conditions for $S$. aureus. The microorganism had enough time and favourable conditions to multiply to the levels above $5 \log \mathrm{CFU} \mathrm{g^{-1 }}$ and synthetize sufficient amount of the detected enterotoxin, The $\mathrm{NaCl}$ content in 2 cheese samples, positive for eneterotoxins was 0.497 and $1.872 \%$. Since $S$. aureus can grow at $20 \% \mathrm{NaCl}$ mentioned values were not inhibitory for the growth and multiplication of the microorganism. Although the number of Lactococcus spp. was more than $7 \log \mathrm{CFU} \mathrm{g}^{-1}$ in cheese samples (Table 5) it had no effect in the reduction of the number of $S$. aureus. Low $\mathrm{pH}$ can cause prophage induction, leading to the expression of gene sea [40] which explains the frequent finding of sea and SEA toxin. Cretenet et al. [35] showed that Lc. lactis can positively or negatively modulate the expression of the genes in the matrix of the cheese. The expression of sea is slightly increased in the presence of Lc. lactis, compared to a strong suppression of sec observed in a cheese matrix in the absence of Lc. lactis. In 
the presence of Lclactis agr control system is reduced with regard to the decrease in the $\mathrm{pH}$ value. A common finding of SEA can be explained by the influence of water activity. The values of water activity $\left(\mathrm{a}_{\mathrm{w}}\right.$ ) for $S$. aureus growth differ from the values for enterotoxin production. The minimum value of $\mathrm{a}_{\mathrm{w}}$ for growth is 0.83 to 0.86 , which is equivalent to the concentration of $20 \% \mathrm{NaCl}$. The optimal value for $S$. aureus growth of is $>0.99$. However, the synthesis of SEA and SED is less susceptible and is possible at approximately the same values of water activity, enabling the growth of S. aureus when other conditions are optimal. In contrast, the synthesis of enterotoxin SEB is very sensitive to lower values of water activity and SEB synthesis at the value of 0.93 is difficult, despite the intensive growth of the microorganism [41], which explains our findings. Water activity influences the enterotoxin C (SEC) synthesis. In addition, aw, low $\mathrm{pH}$ may cause the induction of prophage, resulting in an increase in the expression of genes of sea [40].

Contrary to our results are the results of Rola et al. [42], who proved the presence of $S$. aureus in $56 \%$ of cheese samples produced from raw milk. Although the number of $S$. aureus was $\geq 10^{5} \log \mathrm{CFU} \mathrm{g}{ }^{-1}$, and the maximum value of $2.6 \times 10^{7} \log \mathrm{CFU} \mathrm{g}{ }^{-1}$ the authors did not detect the enterotoxin in cheese samples. Cremonesi et al. [43] showed that none out of 33 cheese samples tested by immunological assays contained SEs but in 14 of 33 samples a mixture of se positive (sea, sec, sed, seg, sel, sej) isolates was identified. Even, Rosengren et al. [24] found levels $>5 \log 10$ CFU g in 16\% (6/39) of raw milk cheeses, the highest level, $6.56 \log 10 \mathrm{CFU}$ g, was detected in raw milk cheese with no starter culture added, SEs (SEA-E) were not detected in any cheese sample. One or more se genes were detected in $50 \%$ of $S$. aureus isolates from traditionally produced raw milk cheese by RT PCR in Turkey. The most frequently SEE (75\%), thus see gene $(61.5 \%)$ was detected, whereas SED and sed gene were not detected in any isolates [44].

The studies conducted in Norway indicated that $14.7 \%$ of CPS isolated at different stages of cheese production were se gene positive (seg and sei) [29].

Although the number of coagulase-positive staphylococci in soft cheese is high it does not mean that expression of gens for enterotoxin synthesis will be possible since cheese is a complex matrix. The different storage conditions after cheese purchasing, as well as temperatures in the refrigerators and short time after the cheeses are consumed do not allow enterotoxigenic staphylococci to produce enough amount of enterotoxins, since out of 26 cheese samples positive for enterotoxigenic staphylococci only in two cheese samples $(7.69 \%)$ enterotoxins were detected. Two cheese samples in which enterotoxin presence was detected were aged 3-4 days and 7 days, the number of coagulase-positive staphylococci exceeded $5 \log \mathrm{CFU} \mathrm{g}^{-1}$. 


\section{CONCLUSION}

Out of 415 cheese overall samples from traditional production, coagulase-positive staphylococci were detected in 85 samples $(20.48 \%)$. The potential for synthesis of classical enterotoxins (SEA-SEE) was detected in $26(30.58 \%)$ coagulase-positive staphylococci isolates, isolated mainly from raw milk cheese samples. Gen sea were present in all, while seb in all but 2 isolates, while sec, sed, see gens were not detected. Enterotoxin was detected in $2(7.69 \%)$ sweet-coagulating raw milk cheese samples in which number of staphylococci exceeded $5 \log \mathrm{CFU} \mathrm{g}{ }^{-1}$.

Strains of $S$. aureus capable of enterotoxin production are highly present. In sweetcoagulating cheeses, made from raw milk in which the number of coagulase-positive staphylococci exceeds $5 \log \mathrm{CFU} \mathrm{g}{ }^{-1}$ and the $\mathrm{pH}$ value is higher than 5.0, enterotoxins may be present in the amounts sufficient to cause intoxication, thus they may represent a risk for human health. The control of $S$. aureus growth during the fermentation of raw milk cheese means prevention of staphylococcal enterotoxin production.

\section{Acknowledgments}

This research was supported by the Ministry of Education, Science and Technological Development of the Republic of Serbia. Project Grant No II 46009.

\section{Authors' contributions}

RSR have made substantional contributions in design of the study; collected samples and did isolation and enumeration of coagulase-positive staphylococci and lactic acid bacteria from cheeses;Identification examing the phenotipic characteristics using ID 32 Staph-Bioemerieux and chemical analysis as well; Writting the manuscript, interprating and representing the obtaind results in the tables and figures; She has given final approval of the version after corrections to be published. BV carried out molecular techniques such as conventional multiplex PCR technique and Rel-Time PCR. Determination of staphylococcal toxins usung ELFA techinque VIDAS Staph enterotoxin SET 2 carried,as well; He has given final approval of the version to be published. NZ participated in the design of the study, performed the statistical analysis and written the part of manuscript.

\section{Declaration of conflicting interests}

The author(s) declared no potential conflicts of interest with respect to the research, authorship, and/or publication of this article. 


\section{REFERENCES}

1. Beuvier E, Buchin S: Raw milk cheeses. In: Cheese: chemistry, physics and microbiology. edn. Edited by Fox PF, Mc Sweeney PLH, Cogan TM, Guinee TP. Amsterdam: Elsevier Academic Press; 2004: 319-345.

2. Euzéby J: List of procaryotic names with standing in nomenclature: - Genus Staphylococcus. In 2012 [http://www.bacterio.ciet.fr/s/staphylococcus.html]

3. Argudin MA, Mendoza MC, Rodicio MR: Food poisoning and Staphylococcus aureus enterotoxins. Toxins 2010, 2 (7):1751-1773.

4. Hennekinne JA, Ostyn A, Guillier F, Herbin S, Prufer AL, Dragacci S: How should staphylococcal food poisoning outbreaks be characterized? Toxins 2010, 2(8):2106-2116.

5. Ono HK, Omoe K, Imanishi K, Iwakabe Y, Hu DL, Kato H, Saito N, Nakane A, Uchiyama T, Shinagawa K: Identification and characterization of two novel staphylococcal enterotoxins types $\mathrm{S}$ and T. Infection and immunity 2008, 76:4999-5005.

6. Balaban N, Rasooly A: Staphylococcal enterotoxins. International journal of food microbiology 2000, 61(1):1-10.

7. Orwin PM, Leung DYM, Tripp TJ, Bohach GA, Earhart CA, Ohlendorf DH, Schlievert PM: Characterization of a novel staphylococcal enterotoxin-like superantigen, a member of the group V subfamily of pyrogenic toxins. Biochemistry 2002, 41(47):14033-14040.

8. Jarraud S, Peyrat MA, Lim A, Tristan A, Bes M, Mougel C, Etienne J, Vandenesch F, Bonneville M, Lina G: $e g c$, a highly prevalent operon of enterotoxin gene, forms a putative nursery of superantigens in Staphylococcus aureus. Journal of immunology (Baltimore, Md : 1950) 2001, 166(1):669-677.

9. Omoe K, Imanishi K, Hu D-L, Kato H, Fugane Y, Abe Y, Hamaoka S, Watanabe Y, Nakane A, Uchiyama $\mathrm{T}$ et al: Characterization of novel staphylococc al enterotoxin-like toxin type $\mathrm{P}$. Infection and immunity 2005, 73(9):5540-5546.

10. Omoe K, Hu DL, Takahashi-Omoe H, Nakane A, Shinagawa K: Identification and characterization of a new staphylococcal enterotoxin-related putative toxin encoded by two kinds of plasmids. Infection and immunity 2003, 71(10):6088-6094.

11. Letertre C, Perelle S, Dilasser F, Fach P: Identification of a new putative enterotoxin SEU encoded by the egc cluster of Staphylococcus aureus. Journal of applied microbiology 2003, 95(1):38-43.

12. Thomas DY, Jarraud S, Lemercier B, Cozon G, Echasserieau K, Etienne J, Gougeon M-L, Lina G, Vandenesch F: Staphylococcal enterotoxin-like toxins U2 and V, two new staphylococcal superantigens arising from recombination within the enterotoxin gene cluster. Infection and immunity 2006, 74 (8):4724-4734.

13. Jablonski LM and Bohach G: Staphylococcus aureus. In: Food microbiology fundamentals and frontiers, $2^{\text {nd }}$ edition - Editors Doyle MP, Beuchat LR. Montville TJ.Washington DC USA: American Society for Microbiology Press 1997; 353-357.

14. Le Loir Y, Baron F, Gautier M: Staphylococcus aureus and food poisoning. Genetics and Molecular Research 2003, 2:7-28.

15. Statistical Yearbook of the Republic of Serbia: [http://publikacije.stat.gov.rs/G2013/ PdfE/G20132010.pdf]

16. Jovanović S, Stanišić M, Maćej O: Specifičnosti proizvodnje kiselokoagulišućih sireva. Acta periodica technologica 2000, 31:109-115. 
17. Rule Book on The quality of dairy products and starter cultures: Rule Book on the quality of dairy products and starter cultures. In.: Official Gazette of Republic of Serbia no. 33/2010, 69 /2010, 43/2013, 34/2014.; 2014.

18. ISO: Microbiology of food and animal feeding stuffs - Horizontal method for the enumeration of coagulase-positive staphylococci (Staphylococcus aureus and other species) - Part 1: Technique using Baird-Parker agar medium In.: International Organization for Standardization; 6888-2:2009.

19. ISO: Fermented milk products - Bacterial starter cultures - Standard of identity. In: International Organization for Standardization. 27205:2010.

20. Carić M, Milanović S, Vucelja D: Standardne metode analize mleka i mlečnih proizvoda. Novi Sad: Prometej; 2000.

21. Araújo VS, Pagliares VA, Queiroz ML, Freitas-Almeida AC: Occurrence of Staphylococcus and enteropathogens in soft cheese commercialized in the city of Rio de Janeiro, Brazil. Journal of Applied Microbiology 2002, 92: 1172-1177.

22. De Luca G, Zanetti F, Stampi S: Staphylococcus aureus in dairy products in the Bologna area. International journal of food microbiology 1997, 35(3):267-270.

23. El-Sharoud WM, Spano G: Diversity and enterotoxigenicity of Staphylococcus spp. associated with domiati cheese. Journal of food protection 2008, 71(12):2567-2571.

24. Rosengren A, Fabricius A, Guss B, Sylvén S, Lindqvist R: Occurrence of foodborne pathogens and characterization of Staphylococcus aureus in cheese produced on farm-dairies. International journal of food microbiology 2010, 144 (2):263-269.

25. Asperger H, Zangerl P: Staphylococcus aureus. In Encyclopedia of Dairy Science. Editors Roginski H, Fuquay J, Fox P, San Diego: Academic Press; 2003, 2563-2569.

26. Boynukara B, Gulhan T, Alisarli M, Gurturk K, Solmaz H: Classical enterotoxigenic characteristics of Stapbylococcus aureus strains isolated from bovine subclinical mastitis in Van, Turkey. International journal of food microbiology 2008, 125(2):209-211.

27. Pelisser M, Klein C, Ascoli KR, Zotti TR, Arisi ACM: Occurrence of S. aureus and multiplex PCR detection of classic enterotoxin genes in chceese and meat products. Brazilian Journal of Microbiology 2008, 40:145-148.

28. Rall VLM, Vieira FP, Rall R, Vieitis RL, Fernandes A, Candeias JMG, Cardoso KFG, Araújo JP: PCR detection of staphylococcal enterotoxin genes in Staphylococcus aureus strains isolated from raw and pasteurized milk. Veterinary microbiology 2008, 132(3-4):408-413.

29. Jørgensen H, Mørkm L, Rørvik L: The occurrence of Staphylococcus aureus on a farm of small-scale production of raw milk cheese. J Dairy Sci 2005, 88 (11):3810-3817.

30. Korpysa-Dzirba W, Osek J: Identification of genes encoding classical staphylococcal enterotoxins in Staphylococcus aureus isolated from raw milk. Bull Vet Inst Pulawy 2011:55-58.

31. Rajić Savić N: Fenotipske i genotipske karakteristike koagulaza pozitivnih stafilokoka izolovanih iz vimena krava. Doctoral dissertation, 2014, Belgrade, University of Belgrade, Faculty of Veterinary Medicine.

32. Hunt K, Jenny S, Peter R, Francis B, Kieran J: Classical enterotoxins of coagulase-positive Staphylococcus aureus isolates from raw milk and products for raw milk cheese production in Ireland. Dairy Sci and Technol 2012, 92(5): 487-499.

33. El-Shenawy M, Tawfeek M, El-Hosseiny L, El-Shenawy M, Farag A, Baghdadi H, Saleh O, Mañes J, Soriano J: Cross Sectional Study of Skin Carriage and Enterotoxigenicity of Staphylococcus aureus among Food Handlers. Open Journal of Medical Microbiology 2014, 4:16-22. 
34. Fueyo JM, Mendoza MC, Martin MC: Enterotoxins and toxic shock syndrome toxin in Staphylococcus aureus recovered from human nasal carriers and manually handled foods: epidemiological and genetic findings. Microbes Infect 2005, 7 (2):187-194.

35. Cretenet M, Even S, Le Loir Y: Unveiling Staphylococcus aureus enterotoxin production in dairy products: a review of recent advances to face new challenges. Dairy Sci \& Technol 2011, 97:127-150.

36. ICMSF ICoMSf: Staphylococcus aureus. In: Microorganisms in foods: Microbiological specifications of food pathogens. edn. Edited by Roberts TA, Baird-Parker AC, Tompkin RB. London: Blackie Academic; 1996: 299-333.

37. Medvedova A, Studenicova A, Valik L, Horvathova Z: Prevalence and growth dynamics of enterotoxigenic Staphylococcus aureus isolates in Slovakian dairy products. Czech J Food Sci 2014, 32(4):337-341.

38. Wieneke AA, Roberts D, Gilbert RJ: Staphylococcal food poisoning in the United Kingdom, 1969-90. Epidemiology and infection 1993, 110 (3):519-531.

39. Kérouanton A, Hennekinne JA, Letertre C, Petit L, Chesneau O, Brisabois A, De Buyser ML: Characterization of Staphylococcus aureus strains associated with food poisoning outbreaks in France. Int J Food Microbiol 2007, 115: 369-375.

40. Schelin J, Wallin-Carlquist N, Cohn MT, Lindqvist R, Barker GC, Rådström P: The formation of Staphylococcus aureus enterotoxin in food environments and advances in risk assessment. Virulence 2011, 2(6):580-592.

41. Hennekinne JA, De Buyser M-L, Dragacci S: Staphylococcus aureus and its food poisoning toxins:characterization and outbreak investigation. FEMS Microbiol Rev 2012 36:815-836.

42. Rola JG, Korpysa-Dzirba W, Osek J: Prevalence of Staphylococcus aureus and staphylococcal enterotoxins at different stages of production of raw milk cheeses-preliminary results. Bull Vet Inst Pulawy 2013, 57:341-345.

43. Cremonesi P, Perez G, Pisoni G, Moroni P, Morandi S, Luyyana M, Brasca M: Detection of enterotoxigenic Staphylococcus aureus isolates in raw milk cheese. Letters in AppliedMicrobiology 2007, 45(6):586-591.

44. Gürbüz S, Oktay K, Sevil E, Gürbilek O, Yasar T, Akın Y, Mehmet D, Cemil D, Hala H: Presence of Staphylococcus aureus, staphylococcal enterotoxins and antimicrobial resistance in traditionally produced raw milk cheeses.Arch Lebensmittelhyg 2018, 69:171-176.

\title{
NALAZ I KARAKTERIZACIJA ENTEROTOKSOGENH STAFILOKOKA IZOLOVANIH IZ MEKIH SIREVA U SRBIJI
}

\author{
SAVIĆ RADOVANOVIĆ Radoslava, ZDRAVKOVIĆ Nemanja, VELEBIT Branko
}

Ukupno 415 uzoraka sireva proizvedenih od sirovog ili kuvanog mleka, prikupljenih sa pijaca ispitano je na prisustvo koagulaza pozitivnih stafilokoka. U $80(20,48 \%)$ uzoraka je dokazano prisustvo koagulaza pozitivnih stafilokoka. Za ispitivanje sposobnosti koagulaza pozitivnih stafilokoka da stvaraju enterotoksine (SEA, SEB, SEC, SED, SEE) i dokazivanje enterotoksina u uzorcima sireva korišćena je ELFA tehnika VIDAS SET 2 (BioMerieux, Francuska). Broj koagulaza pozitivnih stafilokoka u zorcima sireva se kretao od 1-5,79 $\log \mathrm{CFU} \mathrm{g}{ }^{-1}$. Od 85 izolata koagulaza pozitivnih stafilokoka 
$26(30,59)$ je stvaralo enterotoksine. Prisustvo gena za sintezu enterotoksina (SE) u dobijenim ekstraktima DNK iz 26 enterotosogenih izolata je dokazano konvencionalnom multipleks PCR tehnikaom (za gene sea i seb), dok je za genes sec, sed i see korišćena Real-Time PCR tehnika. Kod svih 26 izolata koagulaza pozitivnih stafilokoka (poreklom iz sireva proizvedenih od sirovog ili kuvanog mleka, koji su stvarali enterotoksine) dokazano je prisustvo sea, i kod 24 izolata pored sea gena dokazan je i seb. Nijedan izolat nije imao gene za sintezu C (SEC), D (SED) i E (SEE). Od 26 uzoraka sireva pozitivnih na prisustvo enterotoksogenih koagulaza pozitivnih stafilokoka,enterotoksin je dokazan u 2 (7,69\%) uzorka kiselo-koagulišućeg sira u kojima je broj enterotoksogenih koagulaza pozitivnih stafilokoka bio više od $5 \log \mathrm{CFU} \mathrm{g}^{-1}$. U kiselo-koagulišućim sirevima u kojima je broj koagulaza pozitivnih stafilokoka veći od $5 \log \mathrm{CFU} \mathrm{g} \mathrm{g}^{-1}$ i pH viši od 5, enterotoksin može biti prisutan u količini dovoljnoj da izazove intoksikaciju. 